\title{
Understanding Leaching Behaviour of Landfill Leachate in Benin-City, Edo State, Nigeria through Dumpsite Monitoring
}

\author{
A. F. Aiyesanmi ${ }^{1 *}$ and O. B. Imoisi ${ }^{2}$ \\ ${ }^{1}$ Department of Chemistry, Federal University of Technology, PMB 704, Akure, Nigeria. \\ ${ }^{2}$ Biochemistry Division, Nigerian Institute for Oil Palm Research, NIFOR, PMB 1030, Benin \\ City, Nigeria.
}

Case Study

Received $10^{\text {th }}$ July 2011

Accepted 25 $5^{\text {th }}$ August 2011

Online Ready $4^{\text {th }}$ October 2011

\section{ABSTRACT}

Indiscriminate disposal of solid waste in unauthorized places has become an increasing problem for most cities in Nigeria, especially Benin-City, Edo state. Benin-City one of the largest city in Nigerian is experiencing the problem of solid waste management despite the best attempt of waste avoidance, reduction, reuse and recovery. Use of dumpsites is still the ultimate disposal method of domestic and industrial wastes in Benin-City. Three dumpsites in Benin-City and environs were selected randomly to evaluate their leachates characteristics. Leachate samples were collected from the dumpsites at three months interval and were assessed for their quality through physico-chemical and elemental examination using standard methods for examination of water and wastewater. Physicochemical analysis result showed $\mathrm{pH}$ range of $6.76 \pm 0.08-7.49 \pm 0.02$, EC $(55212.0 \pm 2028.43$ - 64344.33 $\pm 1131.22 \mu \mathrm{S} / \mathrm{cm})$, Temperature $\left(26.03 \pm 0.25-26.60 \pm 0.35^{\circ} \mathrm{C}\right)$, Cyanide $(0.08 \pm 0.04-0.46 \pm 0.01 \mathrm{mg} / \mathrm{L})$, Sulphide $(12.30 \pm 1.21-14.90 \pm 2.26 \mathrm{mg} / \mathrm{L}), \mathrm{BOD}_{5}$ $(61.23 \pm 1.39-98.60 \pm 3.41 \mathrm{mg} / \mathrm{L}), \mathrm{COD}(92.11 \pm 2.14-140.00 \pm 4.19 \mathrm{mg} / \mathrm{L}), \mathrm{NO}_{3}-\mathrm{N} 0.41 \pm 0.03$ - $0.75 \pm 0.09 \mathrm{mg} / \mathrm{L}), \quad \mathrm{NO}_{2}-\mathrm{N}(0.09 \pm 0.01-0.30 \pm 0.03 \mathrm{mg} / \mathrm{L}), \quad \mathrm{TOC} \quad(506.67 \pm 230.94 \quad-$ $573.33 \pm 370.05 \mathrm{mg} / \mathrm{L})$. Metals with consequential environmental significance determined in the leachate samples recorded concentration in $\mathrm{mg} / \mathrm{L}$ as: $\mathrm{Cd}(0.02 \pm 0.01-0.240 .31)$, $\mathrm{Cr}(0.04 \pm 0.00-0.06 \pm 0.01), \mathrm{Cu}(0.49 \pm 0.07-0.61 \pm 0.05), \mathrm{Hg}(0.03 \pm 0.01-0.06 \pm 0.01)$, $\mathrm{Mn}(0.27 \pm 0.07-0.38 \pm 0.03), \mathrm{Ni}(0.05 \pm 0.01-0.07 \pm 0.01), \mathrm{Pb}(0.05 \pm 0.01-0.12 \pm 0.010)$ and $\mathrm{Zn}(0.37 \pm 0.04-0.65 \pm 0.03)$. The physiologic and metabolic roles of the elements detected in the leachate are discussed. The concentrations of the elements detected were below the

*Corresponding author: Email: demolaktp@yahoo.co.uk; ebhodaghebenedicta@yahoo.com; 
toxicity limits recommended by Federal Environmental Protection Agency (FEPA) limits. On the overall, the physico-chemical and elemental characteristics of leachates obtained in this study revealed that the three waste dumpsites generated leachates that were not as contaminated as those reported in some other parts of the world.

Keywords: Dumpsite; leachate; physico-chemical characteristic; metals; Benin-City;

\section{INTRODUCTION}

Leachate can broadly be defined as liquid produced from the decomposition of waste and infiltration of rainwater in the landfill (Keenan et al., 1984). Generation of leachate occurs when sufficient moisture, enough to initiate a liquid flow enters a landfill/dumpsite of refuse and dissolves the contaminants in the landfill/dumpsite into liquid phase. Leachate varies from one dumpsite to another with fluctuations to variation in climate, hydrogeology and waste composition (Speight, 1996). Monroe (2001) also defines leachate as liquid formed when water passes through the waste in the landfill cell. The precipitation can be from rain or the waste itself. As the liquid moves through the landfill/dumpsite many organic and inorganic compounds like heavy metals are transported in the leachate. This moves to the base of the landfill cell and collects.

Increased amount of dumpsite waste as a result of indiscriminate disposal of domestic waste in unauthorized places has become an increasing problem for most cities in Nigerian, as household have fewer or no opportunities for formal recycling or disposal of such waste. Historically, rural and urban waste management has been a serious problem in Nigeria. However, a study conducted by Sridhar et al. (1985) showed that refuse are dumped in gutters, stream and at the back of houses in most cities in Nigeria. The post independent era in Nigeria has witnessed a series of political and socio-economic development vis-a-vis a considerable growth in awareness on environmental pollution problem, which has become a major national and political issue.

Benin-city, one of the largest cities in Nigerian is experiencing the problem of municipal waste management, principally as a result of unplanned development, rural urban migration and natural increase in human population within the city (Akinbiyi, 1992). Demographic expansion and increased industrial and commercial activities have caused an astronomical increase in the volume and diversity of solids wastes generated in the City like most cities in Nigeria (Aluko, 2003).

Although solid waste could be an asset when properly managed, its volume has continued to increase tremendously in recent times in Nigeria, and as a result of socio-economic development including wage increase, much have been and still being invested in municipal solid waste management in cities. But little progress has been made because of several financial constraints within the public and private sector, aside erratic growth of housing units in the inner-core of urban cities (Ojeshina, 1999; Sridhar et al., 1985).

Despite the best attempts of waste avoidance, reduction, reuse and recovery (recycling, composting and energy recovery) landfill and waste disposal sites (such as dumpsite) are still the principal focus for ultimate disposal of residual waste and incineration residues world-wide (Charlotte, 1998). Therefore, waste can be defined as any material gas, liquid or 
solid that is discarded because it's no longer useful to its owner (Henderson, 1984). Municipal refuse waste is material arising from human and animal activities on daily basis. These include garbage, metal scrap, used batteries, wood, cattle dung, sheep goat droppings and litter. All these materials end up at the dumpsite.

As far as pollution of the environmental multi-media by dumpsite leachate is concerned, leachate quality deserves careful scrutiny and analysis to prevent further damage to the environment. It is also essential to understand characteristics of the various types of dumpsite leachate for proper treatment and disposal. Hence, the aim of this paper was to determine dumpsite leachate composition, through physico-chemical and elemental analysis and estimate its polluting effects on the environment and look for cost effective way of treating before disposal. In Benin-City, Nigeria, most people are not aware of the health implication of living close to dumpsite, planting close to dumpsite and eating fruits and vegetable from dumpsite. Plate 1 shows one of the dumpsites in Benin-City close to a farmland and major road.

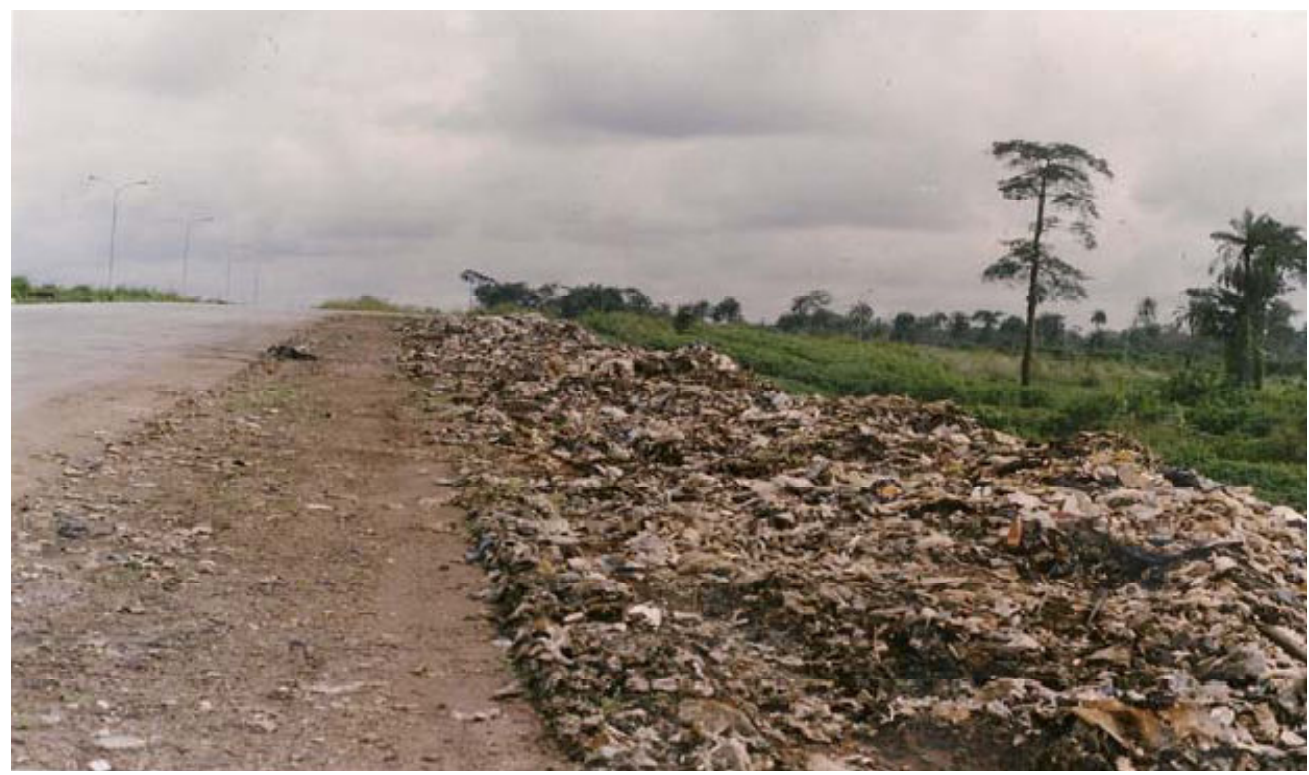

Plate 1: One of the studied dumpsites along the link road in Benin-City, Nigeria

\section{MATERIALS AND METHODS}

\subsection{Study Area}

The location of the dumpsites is within the environs of Benin-City, the capital of Edo State, which lies within the equatorial climate region between latitude and longitude N623.055' to $N$ 6027.339' and E 0536.0018' to E 05⒋130' respectively, and one of the largest cities in southern Nigeria. Benin-City is situated on a branch of Benin River and lies along the main highways from Lagos to the Niger Bridge at Asaba and the eastern states of Nigeria. The city is also linked by roads to Sapale, Siluko, Okene and Ubiaja and is served by air and Niger-River, Delta port of Koko and Sapale. (www.britamea.com/ Benin-City). 


\subsection{Leachate Sample Collection}

Leachate samples, $\mathrm{LW}_{1}, \mathrm{LW}_{2}$ and $\mathrm{LW}_{3}$ were collected from three dumpsites; Otofure, Iguomo and Ikhueniro dumpsite respectively. These dumpsites were situated in three local government areas (Oredo, Ovia Northeast and Ikpoba Okha respectively) within Benin-City and environs (Fig. 1).

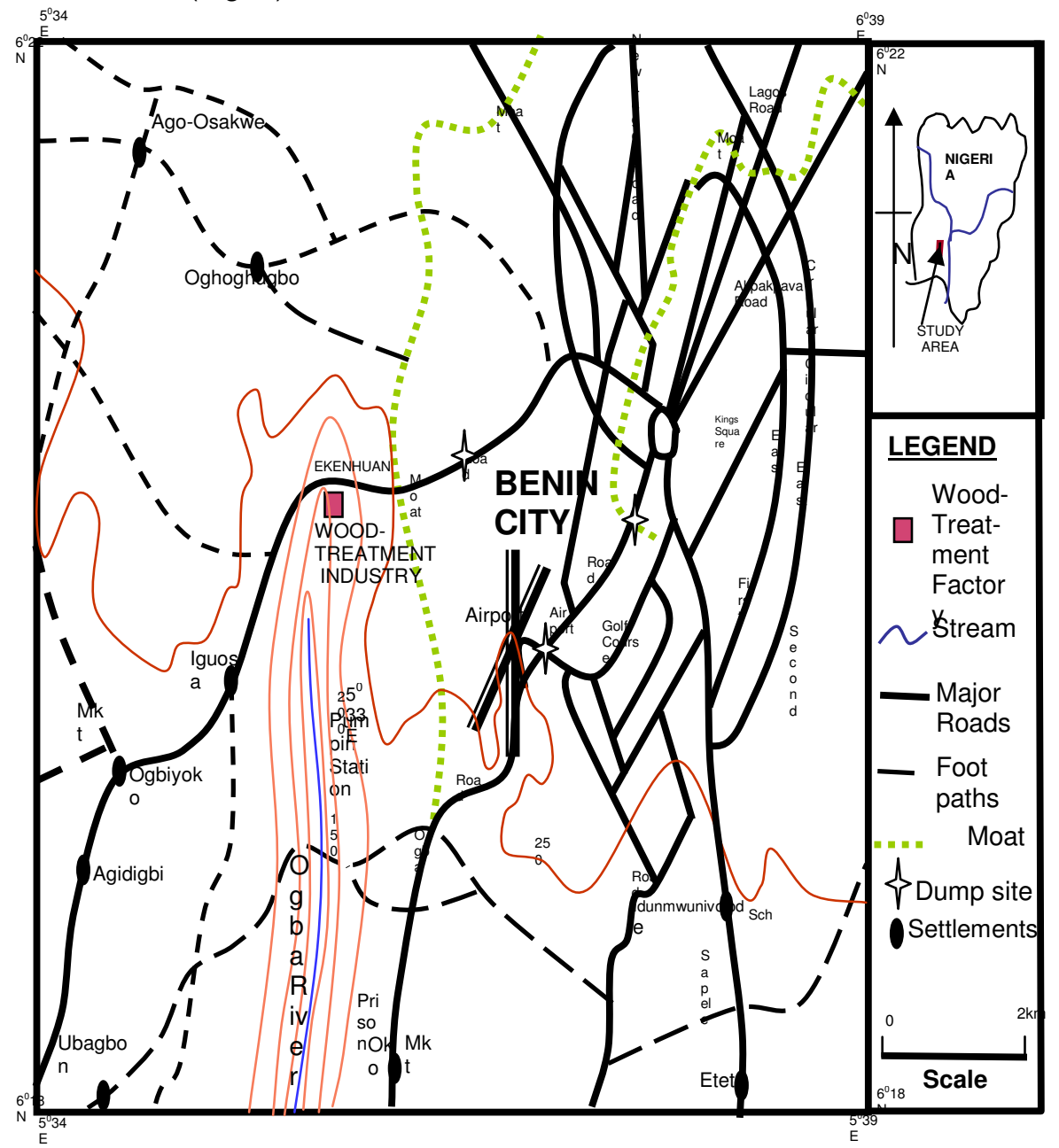

Fig. 1: Map of Benin-City showing the study sites

Samples were collected during the rainy season, from randomly selected leachate drains at the sites. The samples were collected in well labeled clean bottles that were rinsed out with the leachate thrice prior to sample collection. Analytical methods were according to standard methods for examination of water and wastewater stated by APHA (1998). Samples were collected in 1 liter polyethylene bottles and preserved at $4^{\circ} \mathrm{C}$ prior to analysis. Samples for mercury analysis were collected in glass bottles and preserved using $1 \mathrm{ml}$ concentrated $\mathrm{H}_{2} \mathrm{SO}_{4}$ and $1 \mathrm{ml} 5 \% \mathrm{~K}_{2} \mathrm{Cr}_{2} \mathrm{O}_{7}$ solution for every $100 \mathrm{ml}$ samples. Samples for elemental analysis were collected in 1 liter polyethylene bottles and preserved using $2 \mathrm{ml}$ concentrated $\mathrm{HNO}_{3}$. 


\subsection{Laboratory Analysis}

Analyses of leachate samples for physico-chemical and elemental characteristics were carried out as prescribed by APHA (1998) methods for examination of water and wastewater. Total solids and dissolved solids were determined by gravimetric method; colour was determined using HANNA C113 Multi-parameter ion specific Meter, $\mathrm{pH}$ by glass electrode method with a calibrated $\mathrm{pH}$ meter, while temperature and conductivity were determined in-situ using thermometer and conductivity meter respectively. Total alkalinity, total hardness chloride, cyanide, sulphide, and total organic carbon (TOC) were determined by titrimetry. Nitrate, nitrite and ammonia- nitrogen were measured by UV-Visible spectrometer (Unico 2100 series). Turbidity was determined by the Nephelometric method using a potable (HACH metre (DR/890) Data-logging colorimeter). Dissolve oxygen (DO) and biological oxygen demand (BOD) were determined by azide modification of Winkler's method. Open reflux method utilizing potassium tetraoxosulphate (VI) solution in the presence of silver catalyst was used to oxidized the samples for chemical oxygen demand (COD) determination.

One hundred millilitre of samples for elemental analysis were digested using concentrated trioxo-nitrate $(\mathrm{V})$ acid and the volume pre-concentrated and latter made up to $50 \mathrm{ml}$ with deionized water (Ogundiran and Afolabi, 2008). $\mathrm{Na}$ and $\mathrm{K}$ were determined using flame photometer and calcium and magnesium were determined by EDTA titration. While metals ( $\mathrm{Cd}, \mathrm{Cr}, \mathrm{Cu}, \mathrm{Fe}, \mathrm{Mn}, \mathrm{Ni}, \mathrm{Pb}$, and $\mathrm{Zn}$ ) were analyzed using an atomic absorption spectrophotometer (AAS) (Buck Scientific, VGP 210 model), Co, Hg and V were determined colorimetrically using UV-Vissible spectrophotometer (APHA, 1998).

\section{RESULTS AND DISCUSSION}

\subsection{Leachate Physico-chemical Characteristics}

Twenty-one physico-chemical parameters were determined in the leachates samples. The overall result indicated that, the parameters were in varying concentrations in samples from the three dumpsites. This is expected, since physico-chemical characteristics of leachate depend primarily upon the waste composition and water content in total waste (Mor et al., 2006). Although, there was no clear-cut distinction between the characteristic of the leachates to define which constitutes more threats, but some of the parameters recorded lower values in $\mathrm{LW}_{2}$ than in the other dumpsite leachates. It was also observed from the results, that concentrations of these parameters in the leachate samples were low when compared with Federal Environmental Protection Agency (FEPA, 1991) standard for wastewater. The physico-chemical characteristics of the leachate samples are given in Table 1. The levels of all the parameter analyzed in the leachates were generally low except for electrical conductivity (EC), total solid (TS), chloride ion $\left(\mathrm{Cl}^{-}\right)$and colour.

Electrical conductivity $(E C)$ of the leachate sample ranged between $13718.67 \pm 996.56 \mu \mathrm{S} / \mathrm{cm}$ and $64344.33 \pm 1131.22 \mu \mathrm{S} / \mathrm{cm}$, the lowest being from $\mathrm{LW}_{2}$, while the highest was recorded for $\mathrm{LW}_{1}$. High conductivity value of the leachate may be attributed to high dissolved salts and metals in the leachate, and hence it is positively correlated with total dissolved solids (TDS) in solution. Values (23753.8 \pm 7249.30$)$ within the range recorded in this study were reported by Haun-Jung et al. (2005) in Taiwan. Temperature of the leachate samples as measured insitu ranged from $26.03 \pm 0.25^{\circ} \mathrm{C}$ to $26.60 \pm 0.35^{\circ} \mathrm{C}$, falling within FEPA (1991) limit of $\angle 40^{\circ} \mathrm{C}$ 
for wastewater. The level of temperature measured in the leachate samples may probably be due to absorbed heat from the sun and possibly heat of dissolution of some waste material in the dumpsite.

Table 1: Physicochemical characteristics of leachate*

\begin{tabular}{|c|c|c|c|}
\hline Parameters & $\mathrm{LW}_{1}$ & $\mathrm{LW}_{2}$ & $\mathrm{LW}_{3}$ \\
\hline $\mathrm{pH}$ & $7.49 \pm 0.02$ & $6.93 \pm 0.08$ & $6.76 \pm 0.08$ \\
\hline $\mathrm{EC}(\mathrm{us} / \mathrm{cm})$ & $64344.33 \pm 1131.22$ & $13718.67 \pm 996.56$ & $55212 \pm 2028.43$ \\
\hline Temp. $\left({ }^{\circ} \mathrm{c}\right)$ & $26.60 \pm 0.35$ & $26.03 \pm 0.25$ & $26.20 \pm 0.20$ \\
\hline Colour(pt/co) & $1411.67 \pm 1613.82$ & $1825.00 \pm 1325.47$ & $783.33 \pm 128.29$ \\
\hline Turbidity(FTU) & $173.42 \pm 6.97$ & $47.93 \pm 44.09$ & $234.59 \pm 20.34$ \\
\hline $\begin{array}{l}\text { T. Hardness } \\
\left(\mathrm{mgCaCO}_{3} / \mathrm{L}\right)\end{array}$ & $163.39 \pm 39.31$ & $104.86 \pm 3.41$ & $127.65 \pm 6.17$ \\
\hline $\begin{array}{l}\text { Alkalinity } \\
\left(\mathrm{mgCaCO}_{3} / \mathrm{L}\right)\end{array}$ & $23.34 \pm 5.90$ & $77.14 \pm 3.98$ & $13.41 \pm 4.71$ \\
\hline TDS (mg/l) & $32192 \pm 563.78$ & $6830.33 \pm 509.58$ & $28183.33 \pm 1045.48$ \\
\hline $\mathrm{SS}(\mathrm{mg} / \mathrm{l})$ & $11.67 \pm 1.53$ & $3.67 \pm 0.58$ & $22.59 \pm 0.53$ \\
\hline $\mathrm{TS}(\mathrm{mg} / \mathrm{l})$ & $32208.00 \pm 562.79$ & $6834.00 \pm 509.59$ & $28206.00 \pm 1044.99$ \\
\hline Sulphate $(\mathrm{mg} / \mathrm{l})$ & $0.05 \pm 0.01$ & $0.01 \pm 0.00$ & $0.03 \pm 00.1$ \\
\hline Sulphide $(\mathrm{mg} / \mathrm{l})$ & $12.30 \pm 1.21$ & $9.03 \pm 0.37$ & $14.90 \pm 0.26$ \\
\hline Chloride (mg/l) & $1986.63 \pm 198.08$ & $174.27 \pm 8.21$ & $1640.75 \pm 100.05$ \\
\hline $\mathrm{NH}_{4}-\mathrm{N}(\mathrm{mg} / \mathrm{l})$ & $1.64 \pm 0.07$ & $0.63 \pm 0.05$ & $0.56 \pm 0.10$ \\
\hline $\mathrm{NO}_{3}-\mathrm{N}(\mathrm{mg} / \mathrm{l})$ & $0.41 \pm 0.03$ & $0.81 \pm 0.05$ & $0.75 \pm 0.09$ \\
\hline $\mathrm{NO}_{2}-\mathrm{N}(\mathrm{mg} / \mathrm{l})$ & $0.17 \pm 0.01$ & $0.09 \pm 0.01$ & $0.30 \pm 0.03$ \\
\hline TOC $(\mathrm{mg} / \mathrm{l})$ & $506.67 \pm 230.94$ & $573.33 \pm 370.05$ & $540.00 \pm 711.89$ \\
\hline $\mathrm{DO}(\mathrm{mg} / \mathrm{l})$ & $1.40 \pm 0.12$ & $1.60 \pm 0.26$ & $0.93 \pm 0.59$ \\
\hline COD $(\mathrm{mg} / \mathrm{l})$ & $91.47 \pm 1,30$ & $92.11 \pm 2.14$ & $140.66 \pm 4.19$ \\
\hline $\mathrm{BOD}(\mathrm{mg} / \mathrm{l})$ & $67.50 \pm 6.85$ & $61.23 \pm 1.39$ & $98.60 \pm 3.41$ \\
\hline $\mathrm{CN}(\mathrm{mg} / \mathrm{l})$ & $0.08 \pm 0.04$ & $0.36 \pm 0.06$ & $0.46 \pm 0.10$ \\
\hline
\end{tabular}

${ }^{*}$ Means triplicate determination \pm standard deviation

LW: Leachate sample; EC: Electrical Conductivity; TDS: Total dissolved solids; SS: Suspended Solid; TS: Total solids; $\mathrm{NH}_{4} \mathrm{~N}$; Ammonia nitrogen; $\mathrm{NO}_{3}-\mathrm{N}$ : Nitrate; $\mathrm{NO}_{2}-\mathrm{N}$ : Nitrite; TOC: Total organic carbon; DO: Dissolved oxygen; COD: Chemical oxygen demand; BOD: Biochemical oxygen demand; CN: Cyanide

The colour of the leachates ranged between $783.33 \pm 128.29 \mathrm{Pt} / \mathrm{Co}$ and $1825.00 \pm$ 1325.4Pt/Co. The high level of colour may be due to leachate composition and dissolved substances. The colour of leachate collected was dark with offensive smell, showing that it was in septic conditions. The values obtained in this study were however, higher than FEPA (1991) standard of $7.0 \mathrm{Pt} / \mathrm{Co}$ for wastewater. Lower colour value of $426.08 \mathrm{Pt} / \mathrm{Co}$ was reported in similar studies for municipal solid waste landfill site in Ibadan, Nigeria (Aluko et al., 2003), while values below and above what were recorded in this study (580 - 13875 $\mathrm{Pt} / \mathrm{Co}$ units) have been reported in Taiwan (Haun-Jung et al., 2005)

$\mathrm{pH}$ range of $6.76 \pm 0.08$ to $7.49 \pm 0.02$, indicating slightly acidic to slightly alkaline condition were obtained from the samples, with values falling within 6.0-9.0 FEPA (1991) limit for 
wastewater. However, slightly lower values of $(6.78-6.93)$ were reported by Marien et al. (2008) in Tunisia. While slightly higher values of $7.74-7.91$ and 8.17 were reported by Haun-Jung et al. (2005) in Taiwan and Aluko et al. (2003) in Ibadan, respectively, lower to higher values $(5.10-8.60)$ have been reported for landfill leachates in United State of America and Germany (Al-Yaqout and Hamodoa, 2003). pH enhances solubility of metals in leachate, thus elevating their concentration and possibly their toxicity to organisms within their area of influence. Dictated by the $\mathrm{pH}$ values is the measured low alkalinity value of the leachates, which ranged between $13.14 \pm 4.17 \mathrm{mgCaCO}_{3} / \mathrm{L}$ and $23.34 \pm 5.90 \mathrm{mgCaCO}_{3} / \mathrm{L}$. The low alkaline nature of the leachates is attributable to the presence of calcium and magnesium bicarbonate. Alkalinity in wastewater helps to resist changes in $\mathrm{pH}$ caused by the presence of acidic materials in domestic waste.

Turbidity value of leachates ranged between $47.93 \pm 44.09$ FTU and $234.59 \pm 20.34$ FTU with the lowest value recorded in $\mathrm{LW}_{2}$ and highest in $\mathrm{LW}_{3}$. Value within the range obtained in this study has also been reported by Aluko et al. (2003) in Ibadan. High turbidity value may be as a result of decayed organic matter present in the refuse dump, which encourages pathogenic organisms that form tiny colloidal particle. Excessive turbidity may also be associated with unpleasant odours in wastewater.

Nitrate and nitrite levels were in the ranged of $0.41 \pm 0.03-0.81 \pm 0.05 \mathrm{mg} / \mathrm{L}$ and $0.09 \pm 0.01$ $-0.30 \pm 0.03 \mathrm{mg} / \mathrm{L}$ respectively, while that of ammonia-nitrogen was $0.56 \pm 0.10-1.64 \pm$ $0.07 \mathrm{mg} / \mathrm{L}$. The nitrate values were lower than FEPA (1991) limit of $20.00 \mathrm{mg} / \mathrm{L}$. The measured values in this study were also lower than $9.5-20.9 \mathrm{mg} / \mathrm{L}$ reported by Haun-Jung et al. (2005) in Taiwan, while $0.58 \mathrm{mg} / \mathrm{L}$ reported by Aluko et al. (2003) was within the range recorded in the present study. The presence of high nitrate level in leachate can cause pollution of nearby surface water and the groundwater system by increasing their nutrient level.

High chloride level ranging from $174.27 \pm 8.21 \mathrm{mg} / \mathrm{L}$ in $\mathrm{LW}_{2}$ to $1986.63 \pm 198.08 \mathrm{mg} / \mathrm{L}$ in $\mathrm{LW}_{1}$ were obtained in this study, with values higher than $4.0-15.1 \mathrm{mg} / \mathrm{L}$ reported by Chu (1994) for landfill leachates in Hong Kong. The high chloride level reflects significant input of domestic wastes to the dumpsites. Other anions detected in the leachate samples were sulphate $(0.01-0.05 \pm 0.01 \mathrm{mg} / \mathrm{L})$ and sulphide $(9.03 \pm 0.37-14.90 \pm 0.26 \mathrm{mg} / \mathrm{L})$ with values consistently lower in $\mathrm{LW}_{2}$ than in other dumpsite leachates. While the sulphate values recorded in this study were less than $500 \mathrm{mg} / \mathrm{L}$ FEPA limit, sulphide concentrations were, however, higher than $0.20 \mathrm{mg} / \mathrm{L}$ limit. In the same vein, cyanide levels of $0.36 \pm 0.06 \mathrm{mg} / \mathrm{L}$ and $0.46 \pm 0.10 \mathrm{mg} / \mathrm{L}$ recorded in $\mathrm{LW}_{2}$ and $\mathrm{LW}_{3}$, respectively were higher than $0.10 \mathrm{mg} / \mathrm{L}$ FEPA limit, whereas $0.08 \pm 0.04 \mathrm{mg} / \mathrm{L}$ obtained for $\mathrm{LW} 1$ was in conformance with the limit .

Biochemical oxygen demand (BOD) ranged from $61.23 \pm 1.39 \mathrm{mg} / \mathrm{L}$ in $\mathrm{LW}_{2}$ to $98.60 \pm 3.41 \mathrm{mg} / \mathrm{L}$ in $\mathrm{LW}_{3}$, a trend similar to what was obtained for COD levels. BOD values of $12-492$ have been reported for landfill leachates in Taiwan (Haun-Jung et al., 2005), while $795.83 \mathrm{mg} / \mathrm{L}$ was reported for landfill site in Ibadan (Aluko et al., 2003), and $30-600 \mathrm{mg} / \mathrm{L}$, $13400 \mathrm{mg} / \mathrm{L}$ and $400-45900 \mathrm{mg} / \mathrm{L}$ were reported for landfill leachates in Kuwait, USA and Germany respectively (Al-Yaqout and Hamodoa, 2003). BOD in the leachate is due to dissolved biodegradable organic matter in the leachate sample and the values recorded in this study were higher than $50 \mathrm{mg} / \mathrm{L}$ FEPA limit for wastewater. Hence, the leachate could cause increased BOD level of any close-by surface water that may receive storm water from the dumpsites. The COD levels ranged between $91.47 \pm 1.30 \mathrm{mg} / \mathrm{L}$ and $140.66 \pm 4.19 \mathrm{mg} / \mathrm{L}$ far lower than what were reported for landfill leachates in Ibadan, Kuwait, USA, Germany and Taiwan (Aluko et al., 2003; Al-Yaqout and Hamodoa, 2003; Haun-Jung et al., 2005). 
Generally speaking, BOD/COD ratio represented the proportions of biodegradable organics in leachate and were in the order of $\mathrm{LW}_{2}(0.66)<\mathrm{LW}_{3}(0.70)<\mathrm{LW}_{1}(0.74)$ with no significant differences of $\mathrm{BOD} / \mathrm{COD}$ ratios among the three dumpsites. Leachate from young landfill usually had a higher BOD/COD ratio than older or stable one and a BOD/COD ratio of $<0.1$ has been considered for a stable landfill (Haun-Jung et al., 2005).

\subsection{Elemental Analysis}

Fifteen elements including $\mathrm{Na}, \mathrm{K}, \mathrm{Ca}, \mathrm{Mg}, \mathrm{Cd}, \mathrm{Co}, \mathrm{Cr}, \mathrm{Cu}, \mathrm{Fe}, \mathrm{Hg}, \mathrm{Mn}, \mathrm{Ni}, \mathrm{Pb}, \mathrm{V}$ and $\mathrm{Zn}$ ) in leachate were analyzed in this study and listed in Table 2. Consistent with what was reported by Haun-Jung et al., 2005, the concentrations of $\mathrm{Na}, \mathrm{K}, \mathrm{Ca}$ and $\mathrm{Mg}$ were generally the highest among these 15 metals in leachates. $\mathrm{LW}_{1}$, however, showed highest concentrations in $\mathrm{Ca}, \mathrm{Mg}$ and $\mathrm{Na}$ followed by $\mathrm{LW}_{3}$, with the lowest values recorded in $\mathrm{LW}_{2}$. The values also fell in the range reported by Haun-Jung et al. (2005) for landfill leachates in Taiwan and less than $200 \mathrm{mg} / \mathrm{L}$ FEPA (1991) limit for $\mathrm{Ca}$ and $\mathrm{Mg}$ in wastewater. Concentrations measured for $\mathrm{Cd}, \mathrm{Cr}, \mathrm{Cu}, \mathrm{Ni}, \mathrm{Pb}$ and $\mathrm{Zn}$ in leachates were also lower than < $1.0 \mathrm{mg} / \mathrm{L}$ FEPA limit.

Table 2: Metal concentration $(\mathrm{mg} / \mathrm{L})$ in leachate ${ }^{\mathrm{a}}$

\begin{tabular}{lccc}
\hline Metal & LW1 & LW2 & LW3 \\
\hline $\mathrm{Ca}(\mathrm{mg} / \mathrm{l})$ & $105.40 \pm 8.49$ & $81.54 \pm 4.16$ & $92.94 \pm 2.57$ \\
$\mathrm{Cd}(\mathrm{mg} / \mathrm{l})$ & $0.04 \pm 0.01$ & $0.02 \pm 0.01$ & $0.24 \pm 0.31$ \\
$\mathrm{Co}(\mathrm{mg} / \mathrm{l})$ & $0.05 \pm 0.02$ & $0.06 \pm 0.02$ & $0.05 \pm 0.03$ \\
$\mathrm{Cr}(\mathrm{mg} / \mathrm{l})$ & $0.05 \pm 0.02$ & $0.04 \pm 0.01$ & $0.06 \pm 0.01$ \\
$\mathrm{Cu}(\mathrm{mg} / \mathrm{l})$ & $0.49 \pm 0.07$ & $0.51 \pm 0.07$ & $0.61 \pm 0.05$ \\
$\mathrm{Fe}(\mathrm{mg} / \mathrm{l})$ & $3.19 \pm 0.03$ & $1.96 \pm 0.47$ & $2.93 \pm 0.10$ \\
$\mathrm{Hg}(\mathrm{mg} / \mathrm{l})$ & $0.04 \pm 0.00$ & $0.03 \pm 0.01$ & $0.06 \pm 0.01$ \\
$\mathrm{~K}(\mathrm{mg} / \mathrm{l})$ & $452.07 \pm 11.45$ & $123.23 \pm 4.86$ & $462.74 \pm 23.16$ \\
$\mathrm{Mg}(\mathrm{mg} / \mathrm{l})$ & $57.99 \pm 4.99$ & $23.32 \pm 1.04$ & $33.37 \pm 3.05$ \\
$\mathrm{Mn}(\mathrm{mg} / \mathrm{l})$ & $0.38 \pm 0.03$ & $0.27 \pm 0.07$ & $0.37 \pm 0.03$ \\
$\mathrm{Na}(\mathrm{mg} / \mathrm{l})$ & $359.07 \pm 4.68$ & $132.42 \pm 3.83$ & $270.74 \pm 3.38$ \\
$\mathrm{Ni}(\mathrm{mg} / \mathrm{l})$ & $0.05 \pm 0.01$ & $0.05 \pm 0.01$ & $0.07 \pm 0.01$ \\
$\mathrm{~Pb}(\mathrm{mg} / \mathrm{l})$ & $0.11 \pm 0.04$ & $0.05 \pm 0.01$ & $0.12 \pm 0.01$ \\
$\mathrm{~V}(\mathrm{mg} / \mathrm{l})$ & $0.06 \pm 0.00$ & $0.08 \pm 0.01$ & $0.07 \pm 0.01$ \\
$\mathrm{Zn}(\mathrm{mg} / \mathrm{l})$ & 0.54 & $0.37 \pm 0.04$ & $0.65 \pm 0.03$ \\
a means triplicate determination \pm standard deviation &
\end{tabular}

Cadmium $(\mathrm{Cd})$ concentration was between $0.02 \pm 0.01 \mathrm{mg} / \mathrm{L}$ and $0.24 \pm 0.31 \mathrm{mg} / \mathrm{L}$, with higher values of $3.62-8.15 \mathrm{mg} / \mathrm{L}$ reported by Ahlberg, et al. (2006) in Sweden and lower values (< $0.01-<0.15 \mathrm{mg} / \mathrm{L}$ ) reported in Taiwan (Haun-Jung et al., 2005). Cadmium is toxic when inhaled in small quantity as dust during incineration at dumpsite because it is carcinogenic. Nickel (Ni) value ranged from $0.05 \pm 0.01 \mathrm{mg} / \mathrm{L}$ to $0.07 \pm 0.01 \mathrm{mg} / \mathrm{L}$. Comparable values of $0.01-0.07 \mathrm{mg} / \mathrm{L}$ were reported by Huan-Jung et al. (2005) in Taiwan, while higher values of $3.7-2.9 \mathrm{mg} / \mathrm{L}$ were reported by Manpanda, et al. (2007) in Harare, Zimbabwe. Lead (Pb) measured was between $0.05 \pm 0.01 \mathrm{mg} / \mathrm{L}$ and $0.12 \pm 0.01 \mathrm{mg} / \mathrm{L}$. Higher values of $0.35-0.97$ 
$\mathrm{mg} / \mathrm{L}$ were reported by Ahlberg et al. (2006) in Sweden, while similar values $(0.10 \mathrm{mg} / \mathrm{L})$ and less were reported for landfill leachate in Dusseldorf Germany and Taiwan (Haun-Jung et al., 2005). If significant quality of $\mathrm{Pb}$ in leachate is leached into farmland and groundwater, it may cause cytogenetic alteration such as kidney and brain damage or birth defects if ingested through the food chain or drinking water (Ademoroti, 1996). Zinc (Zn) concentration ranged between $0.37 \pm 0.04$ and $0.65 \pm 0.13 \mathrm{mg} / \mathrm{L}$. compared with lower values $(0.003-0.24$ $\mathrm{mg} / \mathrm{L})$ reported by Huan-Jung et al. (2005) in Taiwan and higher values $1.95 \mathrm{mg} / \mathrm{L}$ and $(5.07$ $19.09 \mathrm{mg} / \mathrm{L}$ reported by Aluko et al. (2003) in Ibadan and Ahlberg et al. (2006) in Sweden respectively.

Manganese $(\mathrm{Mn})$ concentration was between $0.27 \pm 0.07 \mathrm{mg} / \mathrm{L}$ and $0.38 \pm 0.03 \mathrm{mg} / \mathrm{L}$. Similar studies on landfill leachates recorded lower values $(0.02-0.18 \mathrm{mg} / \mathrm{L}$ ) in Taiwan (Huan-Jung et al., 2005) and higher values (11.18 - $27.48 \mathrm{mg} / \mathrm{L}$ ) in Ibadan and Sweden (Aluko et al., 2003; Ahlberg et al., 2006). The concentrations recorded in the current study was, however, lower than FEPA (1991) permissible limit of $0.50 \mathrm{mg} / \mathrm{L}$ for wastewater. Similarly, iron (Fe) concentrations of between $1.96 \pm 0.47 \mathrm{mg} / \mathrm{L}$ and $3.19 \pm 0.03 \mathrm{mg} / \mathrm{L}$, which were far below FEPA permissible limit of $20 \mathrm{mg} / \mathrm{L}$ were measured in the leachate samples. Concentrations recorded in this study were within the range reported for some landfill leachates in Hong Kong, Kuwait and Taiwan (Chu, 1994; Al-Yaqout and Hamodoa, 2003; Haun-Jung et al., 2005).

Generally speaking, the concentrations of the potentially toxic metals recorded in the leachate samples were below permissible limits to cause trepidation, this notwithstanding, continuous release of leachate from the dumpsites and consequent transportation via runoff to farmland and surface water or seepage to groundwater could constitute threats to life. Hence, frequent monitoring of leachate and a proactive plan for solid waste management in the study area become imperative.

\section{CONCLUSION}

The results above suggest that, grasping the full picture of pollution potential of landfill leachate is more complex than might at first be supposed. The result obtained from the three dumpsites for metals are of comparable value with one another, while physico-chemical characteristics revealed that the three waste dumpsites generate leachate that were not as contaminated as reported in some parts of the world. This might have been influenced by the variability and heterogeneity of the materials constituting the wastes, age of dumpsite and effects of some environmental factors such as temperature and amount of rainfall at the site. Moreover, all these factors interact and may vary considerably even in the relatively short term. Notwithstanding, the low physico-chemical and elemental characteristics of the leachates in this study, their continuous release into the environment could constitute hazards to the living organisms within their zone of influence, hence, the content of landfill/dumsite must be managed, so that outputs are released into the environment in controlled and acceptable way. The residue left in the site should not pose unacceptable risk to the environment and the need for after care monitoring should be considered as top priority by the Edo State Government of Nigeria.

This research work constitutes part of the on- going studies on dumpsite leachate characterization and effects on groundwater in Edo State, Nigeria. Results of study on quality characteristics of groundwater close to the dumpsites will soon be published. This is germane to the assessment of groundwater contamination and generation of adequate data 
to arrive at a more holistic conclusion on the interaction between leachate and groundwater and the effects as related to the faith of people living around the dumpsites.

\section{COMPETING INTERESTS}

Authors have declared that no competing interests exist.

\section{REFERENCES}

Ademoroti, C.M.A. (1996). Environmental Chemistry and toxicology. Foludex Press Ltd. Ibadan, Nigeria.

Ahlberg, G. Gustafssion, O. Wedel, P. (2006). Leaching of metals from sewage sludge during one year and their relationship to particle size.J. Environ. Pollut., 144(2), 545 553

Akinbiyi, R. (1992).Improving the urban environment. Afr. Health., 15(1), 26.

Aluko, O.O., Sridhar, M.K.C., Oluwande, P.A. (2003). Characterization and treatment of leachate from municipal solid waste landfill site in Ibadan, Nigeria. J. Environ. Health Res., 2(1), 32-37.

Al-Yaqout, A.F., Hamdoa, M.F. (2003). Evaluation of landfill leachate in arid climate-a case study. Environ Int., 29, 593-600.

APHA. (1998). Standard Methods for the Examination of Water and Wastewater, $20^{\text {th }}$ ed. APHA-AWWA-WPCF, Washington DC,USA

Charlotte, Y. (1998). Applying COSHH principles to waste management. Environ. Health J., 106(10), 289 - 291.

Chu, L. M. (1994). Variations in the chemical properties of landfill leachate. Environ. Manage., 18(1), 105- 17.

FEPA. (1991). Guidelines and Standard for Industrial Effluents, Gaseous Emissions and Hazardous Wastes Management in Nigeria. Federal Environmental Protection Agency.

Henderson, S.B. (1984). Text on Pollution of our Atmosphere. Adam Harilger Ltd Briton.

Huan-Jung, F., Hung-Yee, S., Hsin-Shin, Y., Wen-Chin, C. (2005). Characterization of landfill leachate in central Taiwan. J. Sci. Total Environ., 361, 25 - 37.

Keenan, J.D., Steiner, R.L., Fungaroli, A.A. (1984). Landfill leachate treatment. J. Water Poll. Contr. Fed., 56(1), 27-33.

Mapanda, F. Nyamadzawo, G. Nyamangara, J. Wuta, M. (2007). Effects of discharging acidmine drainage evaporation pond limed with clay on chemical quality of the surrounding soil and water. J. Phy. Chem. Earth., 32, 1366 - 1375.

Marien, E., Fathi, A., Sami, S. (2008). Detoxification of Tunisian landfill leachates by selected fungi. J. Hazard. Mat., 150, 642-648.

Monroe, M. (2001). Textbook on landfill leachate treatment: VSEP Offers a Revolutionary Solution. www.vsep.com/company/articles/2.html

Mor, S., Ravindra, K., Dahiya, R.P., Chandra, A. (2006). Leachate characterization and assessment of groundwater pollution near municipal solid waste landfill site. Environ. Monitor. Assess., 118, 435-456

Ogundiran, O. O., Afolabi, T. A. (2008). Assessment of the physicochemical parameters and heavy metals toxicity of leachates from municipal solid waste open dumpsite. Int. J. Environ. Sci. Tech., 5(2), 243-250. 
Ojeshina, O.A. (1999). Sanitary and hazardous waste: Landfill as a waste disposal strategy for Nigerian, settlement. A paper presented at one day workshop as part of the activities to mark FEPA's $10^{\text {th }}$ Year Anniversary, Lagos, Nigeria.

Speight, J.G. (1996). Environmental Technology Handbook. Applied Energy Technology Series. Taylor and Francis.

Sridhar, M.K.C., Bammeke, A.O, Omishakin, M.A. (1985). A study on the characteristics of refuse in Ibadan, Nigeria. J. Waste Manage. Res., 3, 191- 201.

(c) 2011 Aiyesanmi \& Imoisi; This is an Open Access article distributed under the terms of the Creative Commons Attribution License (http://creativecommons.org/licenses/by/3.0), which permits unrestricted use, distribution, and reproduction in any medium, provided the original work is properly cited. 